\title{
STRENGTH TESTS ON NEWLY FALLEN SNOW
}

\author{
By R. Perla \\ (U.S. Forest Service, Alta Avalanche Study Center, Alta via Sandy, Utah 84070 , U.S.A.)
}

\begin{abstract}
Modified versions of in situ strength tests previously applied to metamorphosed snow were developed to measure the mechanical properties of newly fallen snow during storm periods. A large drop-cone penetrometer, protected from the wind by an aluminum shell, was used to determine snow "hardness". A lightweight model of the Haefeli ram penetrometer measured "ram numbers". Shear strengths were obtained from large, light-weight frames. Some preliminary tests were made with a shear vane driven by a torque wrench. A new technique was devised for measuring tensile strength whereby a cantilever beam of snow is undercut until it fails under its own weight. Comparisons between the cantilever test and the shear-frame test show high ratios for tensile to shear strength. Cantilever strength plotted against density shows an order of magnitude variation in strength at all densities.
\end{abstract}

RÉsumé. Test de résistance sur neige fraíche. Des versions modifiées de tests de résistance in situ appliqués auparavent à la neige métamorphosée furent développés pour mesurer les propriétés mécaniques de neige fraîche tombée pendant les périodes de tempête. Un large pénétromètre cônique, protégé du vent par une enveloppe d'aluminium, fut utilisé pour détérminé la dureté de la neige. Un modèle léger de pénétromètre modèle Haefeli - mesurait les nombres de battage. On obtint les résistances au cisaillement au moyen de larges cadres légers. Quelques tests préliminaires furent établis au moyen d'une sonde de cisaillement actionnée par torsion. Une nouvelle technique fut élaborée pour mesurer la résistance d'élongation en coupant par dessous une poutre cantilever de neige jusqu'à sa rupture sous son propre poids. Des comparaisons entre le test cantilever et le test de cisaillement montrent de forts rapports entre la contrainte d'elongation de grandeur de la contrainte pour toutes les densités.

Zusammenfassung. Festigkeitsuntersuchungen an Neuschnee. Zur Messung der mechanischen Eigenschaften von bei Sturm gefallenem Schnee werden Methoden für Festigkeitsuntersuchungen in situ modifiziert, die bisher in metamorphem Schnee angewendet worden waren. Eine grosse konische Fallsonde, durch eine Aluminiummuschel gegen den Wind geschützt, wurde zur Bestimmung der Härte des Schnees benutzt. Mit einer Haefeli-Rammsonde in Leichtbauweise wurden Rammzahlen gemessen. Die Scherfestigkeit erhielt man mit grossen, leichten Rahmen. Einige Voruntersuchungen wurden mit einem Scherflügel, angetrieben durch einen Drehschlüssel, durchgeführt. Zur Messung der Zugfestigkeit, wurde eine neue Technik entwickelt, bei der ein Kragender Schneebalken solange unterhöhlt wird, bis er unter seinem Eigengewicht abbricht. Vergleiche zwischen dem Überhangtest und dem Test mit Scherrahmen ergeben hohe Verhältniszahlen zwischen Zug- und Scherfestigkeit. Die Überhangfestigkeit, als Funktion der Dichte aufgetragen, ändert sich um eine Grössenordnung über den ganzen Dichtebereich.

\section{INTRODUCTION}

In many regions affected by avalanches, the most dangerous conditions arise during storms. This is partially due to the structural instability of the newly fallen snow (LaChapelle, 1967). Measurements of the mechanical characteristics of fresh snow pertinent to avalanche formation must be made during and immediately after storms.

Because of their fragility, samples of newly fallen or weakly metamorphosed snow usually are disturbed in transit despite careful handling. The alternative is to test the snow in situ. Although the literature contains many references to in situ testing of metamorphosed snow, reports confined to such measurements of newly fallen snow are scarce. Roch (1966) performed systematic in situ tests on alpine snow profiles. His techniques were designed to test snow in various stages of metamorphism; consequently, his fresh-snow measurements did not discriminate among the many possible varieties of newly fallen snow. Keeler and Weeks ( I 988 ) explored the consistency of various in situ test schemes. However, like Roch, they were primarily interested in the entire profile of the alpine snowpack. Martinelli (in press) measured the properties of freshly deposited snow in the starting zone of several avalanches, and suggested several of the modifications reported in this paper.

Many difficulties are encountered in setting up consistent experiments on fresh snow. An important problem is the structure and property variation in the $Z$-direction (Fig. I) which 
necessitates sampling the entire profile of newly fallen snow at closely spaced intervals. For most tests, a practical interval is $5 \mathrm{~cm}$. The problem of variation in the $X$ - and $Y$-directions can be minimized by the choice of a suitable study area, free from wind and precipitation anomalies. Because of rapid metamorphism, measurements must be taken at $8 \mathrm{~h}$ intervals during the storm period. Finally, the tests must be performable during blizzard conditions, and must cover a strength range of at least two orders of magnitude.

This report summarizes the development of four in situ tests which overcome the above difficulties. The drop-cone penetrometer, the ram penetrometer, and the shear frame are modified versions of devices previously applied to metamorphosed snow. A cantilever test is introduced for measuring tensile strength.

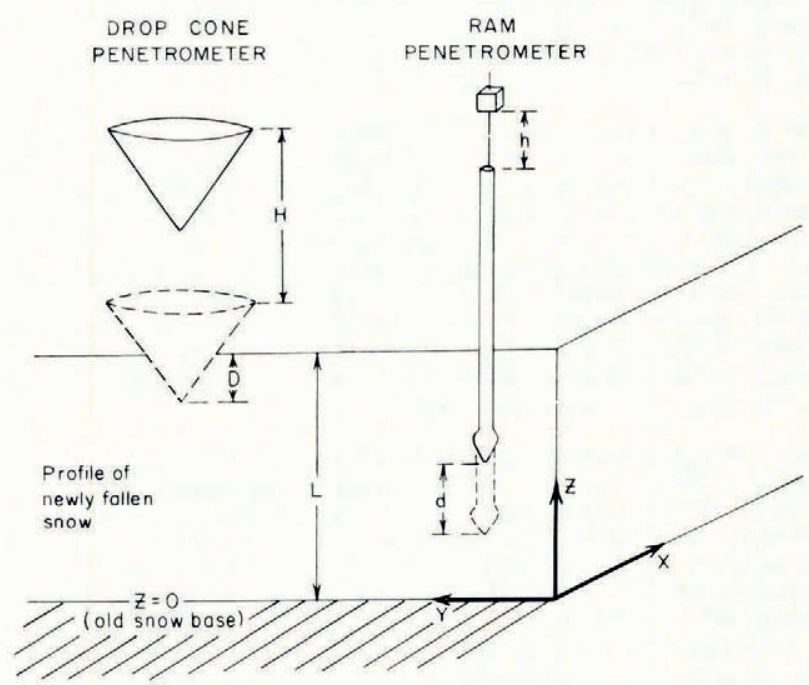

Fig. I. Reference systems.

\section{Drop-cone Penetrometer}

Drop-cone penetrometers have provided self-consistent values for hardness of snow. Takahashi and Kudo (I94I) performed drop-cone experiments on snow in the density range of 250 to $420 \mathrm{~kg} \mathrm{~m}^{-3}$. Their data led to the following relationship:

$$
U=m g H=q D^{p}
$$

where $U$ is the energy of impact, $m$ the mass of the drop cone, $g$ the acceleration due to gravity, $H$ the distance of fall (Fig. I), $D$ the depth of penetration (Fig. I), and $q$ and $p$ are constants related to the snow structure. They defined hardness of the snow, $P$, as simply:

$$
P=U / V
$$

where $V$ is the volume of the depression. Inaho (I94I) applied the drop cone to a variety of snow types. In his experiments, $p$ ranged from 1.6 to 5.2. This showed the limitation of the hardness definition given by Equation (2) which assumes $p=3$. Other drop-cone experiments have been reported by Bader and others (195I); Yosida (1957); and Anisimov and others (1958). Drop-cone hardness of clay has been related to shear strength by Hansbo (I957).

At the Alta Avalanche Study Center, a drop-cone penetrometer was developed for testing freshly fallen snow. Its operation (Fig. 2) is as follows: the instrument rests on the snow, supported by its flange in a level position. The cone assembly is held up by the clamp. The 
operator looks through the observation window, loosens the clamp, gently lowers the cone assembly until it makes contact with the snow, and notes the meter stick reading, $Z_{\mathrm{r}}$. The cone assembly is then lifted to an initial $z_{\mathrm{r}}$ reading on the meter stick, released and allowed to fall, penetrate the snow, and come to rest at position $Z_{2}$.

The distance of fall and depth of penetration are, respectively,

$$
\begin{aligned}
& H=z_{2}-z_{1}, \\
& D=z_{2}-z_{r} .
\end{aligned}
$$

$U$ can be increased by decreasing $Z_{\mathrm{I}}$ (that is, raising the cone assembly) or by adding weights to the cone assembly.

Previous drop-cone models measured the diameter of the conical impression. This was a time-consuming operation and restricted the experimenters to two or three drops per determination of $U$. Using the procedure described above, the operator can make quickly 5 to io drops for each determination. The aluminum frame provides ample protection from the wind during blizzard conditions.

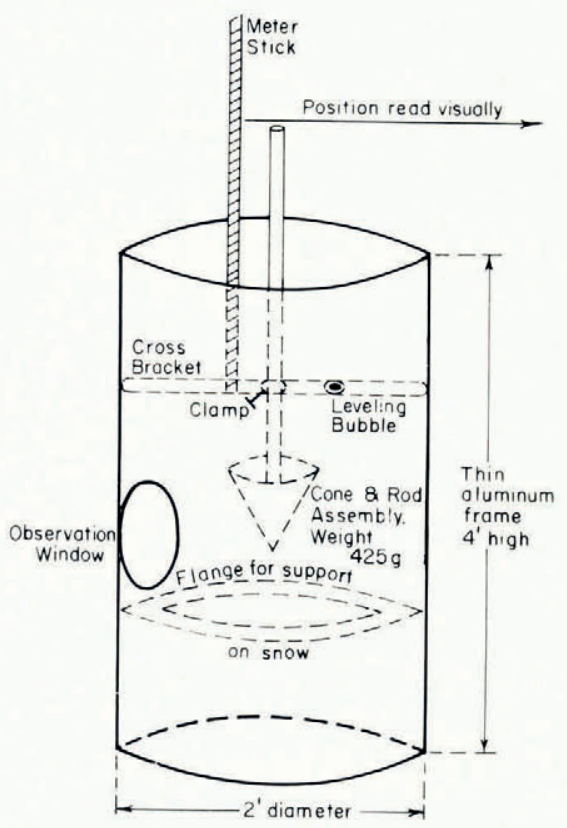

Fig. 2. The Alta drop-cone penetrometer.

Provision was made for using $120^{\circ}, 90^{\circ}, 60^{\circ}$, and $45^{\circ}$ cones. Comparative studies were made and $60^{\circ}$ cones, with base diameters 15,25 , and $40 \mathrm{~cm}$, were selected as most suitable. Though $120^{\circ}$ and $90^{\circ}$ cones gave consistent results, the base diameter of these cones would have to be large to allow for deep slab penetration. The $45^{\circ}$ cone was disqualified because of a peculiar inconsistency; certain snow types would fracture around the impact point of this narrow-angle cone.

On a $\log$-log diagram, $U$ is approximately a linear function of $D$ (Fig. 3); in most cases this is an excellent approximation. From the log-log diagram it is possible to determine $p$ and $q$ of Equation (I).

Because penetration is a complex process, it is difficult to uncover intrinsic values of strength or resistive pressure from Equation (I). Mellor (I964) summarizes some of the power relationships that have been used, and Kinosita ( 1967$)$, making a distinction between brittle 
and plastic failure, reports power relationships for the force which resists the intrusion of a cone. In newly fallen snow, it is useful to derive power relationships for resistive pressure directly from Equation ( $\mathrm{I}$ ), by lumping all of the mechanisms that resist penetration into a generalized force

Then, from Equation ( $\mathrm{I}$ )

and

$$
\boldsymbol{F}=-\nabla U
$$

For a $60^{\circ}$ cone, an incremental band of area is

$$
\mathrm{d} S=4 \pi D \mathrm{~d} D / 3 .
$$

The resistive pressure, $P$, is

$$
P=\frac{\mathrm{d} F}{\mathrm{~d} S}=\frac{3 q(p-\mathrm{I}) p D^{p-3}}{4^{\pi}}
$$

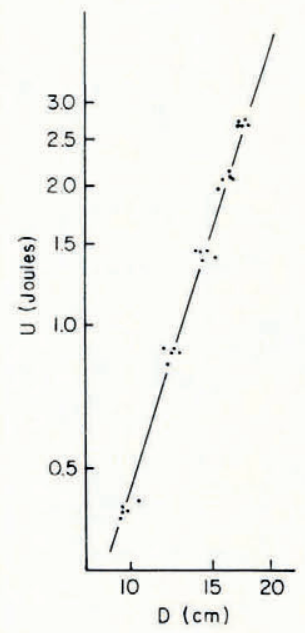

Fig. 3. Impact energy $(U)$ as a linear function of penetration $(D)$ on a log-log diagram; newly fallen snow, density $I_{1} \mathrm{O} \mathrm{kg} \mathrm{m}^{-3}$

\begin{tabular}{|c|c|c|c|c|c|c|}
\hline Date & Time & $\begin{array}{l}\text { No. of } \\
\text { Samples }\end{array}$ & $\begin{array}{l}\text { Density } \\
\mathrm{kg} \mathrm{m}^{-3}\end{array}$ & $q \times 10^{4}$ & $p$ & $\begin{array}{l}\text { Hardness no. } \bar{P}^{*} \times 10^{4} \\
\mathrm{~N} \mathrm{~m}^{-2}\end{array}$ \\
\hline 26 February & 13.00 & 10 & 100 & 0.54 & 3.75 & 6 \\
\hline $14 \mathrm{March}$ & 15.00 & 25 & 120 & 0.14 & 4.40 & 9 \\
\hline I5 March & I 1.00 & 10 & I 80 & I. 18 & 3.70 & I I \\
\hline $16 \mathrm{March}$ & 15.00 & II & 310 & $0.3^{8}$ & 4.40 & 24 \\
\hline I9 March & 08.00 & 17 & 120 & $0.3^{0}$ & 3.89 & 5 \\
\hline I9 March & 15.00 & 25 & I IO & I. $9 \mathrm{I}$ & $3 \cdot 36$ & 7 \\
\hline 29 March & 15.00 & 20 & 170 & $2.5^{6}$ & $3 \cdot 40$ & 10 \\
\hline $30 \mathrm{March}$ & I I.OO & 15 & 100 & 0.75 & $3 \cdot 52$ & 4 \\
\hline 3o March & 17.00 & 28 & 210 & $34.80 \dagger$ & $2.5^{6}$ & 20 \\
\hline I April & 15.00 & 15 & 70 & 1. 23 & $3 \cdot 40$ & 5 \\
\hline I 3 April & I 1.00 & 20 & 210 & 0.33 & $4 \cdot 4^{2}$ & 22 \\
\hline 6 May & 17.00 & 20 & $39^{\circ}$ & 0.55 & $4 \cdot 30$ & 26 \\
\hline I I May & 15.00 & 15 & I 10 & 1.57 & 3.26 & 5 \\
\hline I3 May & 17.00 & 10 & 100 & 0.27 & 3.84 & 4 \\
\hline
\end{tabular}
19 March 1967 , Alta.

Table I. Drop-cone Penetrometer Experiments, Alta, i 967

* $\bar{P}$ based on $L=15 \mathrm{~cm}$.

$\dagger$ Ice crust was present on the surface. 
Finally, the "hardness number", $\bar{P}$, of a layer is defined as an average of the resistive pressure taken over the thickness of the layer, $L$,

$$
\bar{P}=\frac{\mathrm{I}}{L} \int_{\mathrm{o}}^{L} P \mathrm{~d} D=\frac{3 q p(p-\mathrm{I}) L^{p-3}}{4 \pi(p-2)} .
$$

Clearly, the thicker the layer, the more resistance it offers to conical penetration. For comparison of snow types, all values of $\bar{P}$ should be based on the same value of $L$.

Some results of drop cone experiments performed in the spring of 1967 are shown in Table I.

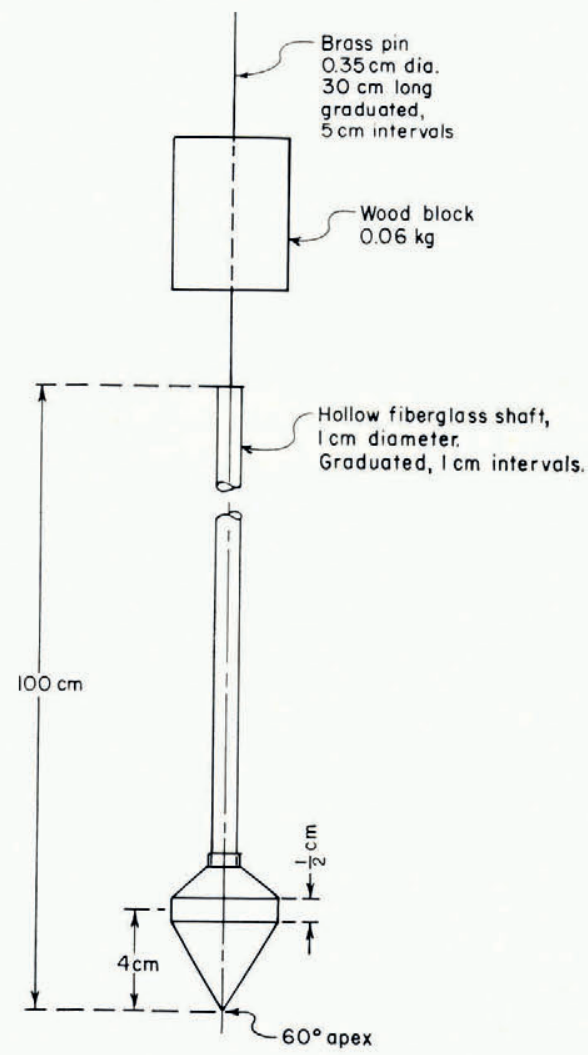

Fig. 4. Ram penetrometer. Mass, o.o6 kg (not including wood block).

\section{Ram Penetrometer}

A ram penetrometer for measuring the relative mechanical strength of snow was designed by Haefeli (Bader and others, 1939). Each winter this instrument is used in many alpine regions to determine the strength changes of the snow profile in relation to the avalanche hazard. Correlations have been established between this well-known instrument and intrinsic snow properties (Keeler and Weeks, I968).

The Haefeli penetrometer is too heavy (about $\mathrm{I} \mathrm{kg}$ per section) to be used on newly fallen snow. On a suggestion by M. Martinelli, a light-weight ram was designed at Alta (Fig. 4) and applied to newly fallen snow during the season $1967-68$. 
Haefeli (Bader and others, I939) recommended a "ram number" defined by

$$
W_{\mathrm{I}}=\frac{R h}{d}+R+Q,
$$

where $R$ is the weight of the driving hammer, $h$ the height of fall of the driving hammer (Fig. I), $d$ the depth of penetration (Fig. I), $Q$ the weight of the penetrometer, not including the hammer, and $W_{\mathrm{I}}$ the ram number.

Equation (7) is based on a coefficient of restitution, $\eta=1$. Haefeli demonstrated that a ram number, $W_{\eta}$, could be derived in terms of a general $\eta$

$$
W_{\eta}=\frac{h\left(\mathrm{I}+\eta^{2}\right) / 2 d+2}{h / d+2} W_{\mathrm{I}} .
$$

He chose Equation (7), however, partially because of its simplicity and partially because he felt $\eta$ would have a high value owing to a low ratio of strain energy of the penetrometer to total impact energy. This last argument was not clear and Waterhouse (1966) recommended replacing Equation (7) with an equation equivalent to Equation (8).

Based on data compiled by Chellis (I96I), a reasonable value of $\eta$ for the Alta ram is $\eta=0.5$. Then Equation (8) becomes

$$
W_{\eta}=\frac{0.63 h / d+2}{h / d+2} W_{\mathbf{r}}
$$

When the Alta ram is applied to a moderately strong layer of newly fallen snow, $h / d$ may be 10 or larger, and, from Equation (9),

$$
\frac{W_{\eta}}{W_{\mathrm{I}}} \approx 0.70 .
$$

Thus the corrections are important, and Equation (9) should be used when a consistent comparison is desired between the ram and other tests.

Olson and Flaate ( 1967 ) summarize various formulas that could possibly replace Equation (9) and avoid the use of $\eta$. On the other hand, Equation (9) is in convenient form for correcting $W_{1}$, the ram number used in most previous studies.

In contrast to metamorphosed snows which typically have ram numbers of the order of Io to $10^{2} \mathrm{~kg}\left(1^{2}\right.$ to $\left.\mathrm{IO}^{3} \mathrm{~N}\right)$, the ram numbers of newly fallen snows are of the order of $\mathrm{IO}^{-\mathrm{I}}$ to $\mathrm{I} \mathrm{kg}$ ( $\mathrm{I}$ to Io $\mathrm{N}$ ).

The main advantage of the ram is its ease and speed of use. A $3 \mathrm{~m}$ thick layer of newly fallen snow can be tested in about $2 \mathrm{~min}$. Other tests which depend on digging snow pits and slicing out samples are far more time-consuming.

From some preliminary experiments, the Alta ram appears suitable for strength tests at the fracture zone of avalanche slopes during periods of soft slab formation.

Unfortunately, the ram number is related to the complex mechanism of penetration rather than direct shear or tensile strength. Difficulties can be expected when attempts are made to correlate the ram number with intrinsic snow properties despite the careful selection of a relationship such as Equation (9).

\section{Shear Frame}

Since the intrinsic properties of newly fallen snow are not easily derived from penetration experiments it is preferable to devise tests which measure directly the properties in question. Such tests will generally require more patience from the observer than the expedient penetration tests. With sufficient experimental data, it may be possible to establish meaningful correlations between various tests; eventually, only the simple and quick tests would be retained. 
The Alta shear frame (Fig. 5a) is a modification of a shearing apparatus introduced by Roch (de Quervain, I950). Since new snow has a wide range of strength, two separate frames are necessary. Both frames have the same dimensions; however, one frame is fabricated from very thin gage aluminum (about $0.75 \mathrm{~mm}$ ) so that it is easily supported by weak, low-density snow; the second frame is fabricated from thicker gage aluminum (about I.5 mm) and can be used on stronger snows. A low-range spring scale (o-IO N) is used to pull the light frame; a higher range scale $(0-100 N)$ is used on the heavier frame. The scales are equipped with memory attachments. Readings are taken at $5 \mathrm{~cm}$ intervals in the wall of a snow pit.

Roch (I966) reported consistent measurements with a rate of loading that induced failure between $\mathrm{I}$ and $2 \mathrm{~s}$ after the initial application of the force. This rate is facilitated by a rapid but smooth pull on the spring scale. All of the tests reported in this paper presume brittle-type failure which can be achieved by the rapid application of stress (Kinosita, I967).

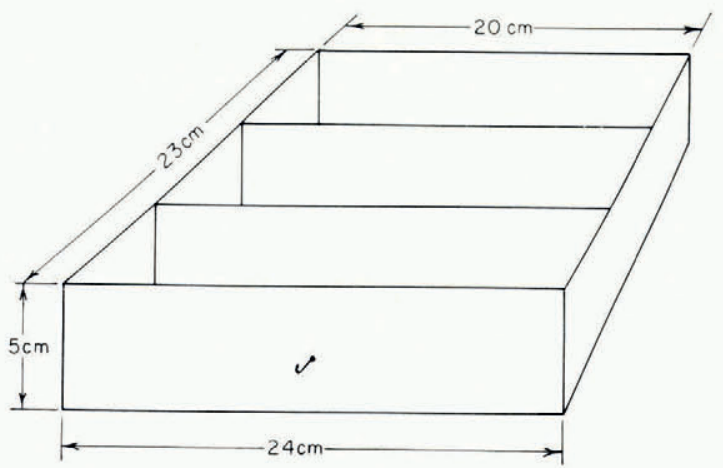

Fig. 5a. Shear frame suitable for newly fallen snow.

Table II. Comparison of Shear-frame Strength $\tau$ and Beam Number $B$ for Newly Fallen Snow Alta, ig68

\begin{tabular}{cccccc}
$Z$ & & \multicolumn{2}{c}{ Shear-frame } & \multicolumn{2}{c}{ Cantilever beam } \\
$\mathrm{cm}$ & $\mathrm{P}$ & $F$ & $\tau$ & $\lambda$ & $B$ \\
$37-32$ & $\mathrm{~kg} \mathrm{~m}$ & $\mathrm{~N}$ & $\mathrm{~N} \mathrm{~m}^{-2}$ & $\mathrm{~cm}$ & $\mathrm{~N} \mathrm{~m}^{-2}$ \\
$3 \mathrm{I}-26$ & 103 & 6.9 & 138 & 8 & 389 \\
$25-20$ & $\mathrm{I} 30$ & 14.7 & 294 & $1 \mathrm{I}$ & 925 \\
$19-14$ & $\mathrm{I} 33$ & 19.6 & 392 & 14 & 1530 \\
$13-8$ & 146 & 34.3 & 696 & $2 \mathrm{I}$ & 3840 \\
$7-2$ & 165 & 40.2 & 804 & 24 & 5520
\end{tabular}

The shear strength of the snow $\tau$ is maximum force $F$ divided by area of frame, which for the Alta unit is

$$
\tau=\left(20 \mathrm{~m}^{-2}\right) F
$$

Some typical values of shear strength calculated according to Equation (I0) are shown in Table II.

Roch ( 1966) determined the Coulomb-Mohr envelopes of his samples by placing various weights on a glass plate. He was able to verify Haefeli's prediction (Bader and others, I939) with respect to fresh snow, that a small normal load on the shear frame tends to break the dendritic branches and cause a slight reduction in strength. Roch also observed an increase in strength with an increase in normal loading, but he judged that the increased loading caused the fresh snow to densify by successive failures with a major alteration in the structure of the original test specimen. It is anticipated that Roch's technique of normal loading can be applied to freshly fallen snow; further investigations are planned. 
Closely related to the shear frame is the shear vane (Fig. 5 b). The moment $M$ applied by the torque wrench at the instant of failure is balanced by the shear strength $\tau$ so that

$$
M=2 \int_{0}^{2 \pi} \int_{0}^{l_{2}} \tau r^{2} \mathrm{~d} r \mathrm{~d} \theta+2 \pi l_{1} l_{2}{ }^{2} \tau .
$$

Suggested dimensions for use on newly fallen snow are $l_{\mathrm{r}}=5 \mathrm{~cm}$ and $l_{2} \approx$ I0 $\mathrm{cm}$. Because a snow pit is not required for its operation, the shear vane is a faster test than the shear frame. Development of this technique is planned for 1969 .

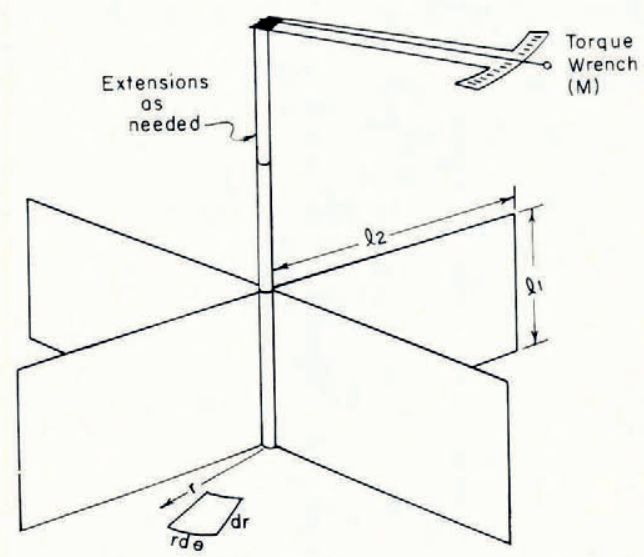

Fig. 5 b. Shear vane.

\section{Cantilever Beam}

Tensile strength of alpine snow has heretofore been determined by a centrifugal test (Fig. 6) (de Quervain, I950), and calculated from

$$
\sigma=\frac{\mathrm{I}}{S} \int_{0}^{l} \frac{v^{2}}{r} \mathrm{~d} m
$$

where $\sigma$ is the tensile strength, $S$ the cross-sectional area of the cylinder, $2 l$ the length of the cylinder, $\mathrm{d} m$ the mass of the infinitesimal disc, $r$ the distance of the disc from the axis of rotation, and $v$ the linear speed of the disc at failure.

This test appears to be reliable and may offer a true indication of the actual tensile strengths of small cylindrical samples. Unfortunately, cylindrical samples of newly fallen snow are not easily collected; an alternative for measuring tensile strength is needed.

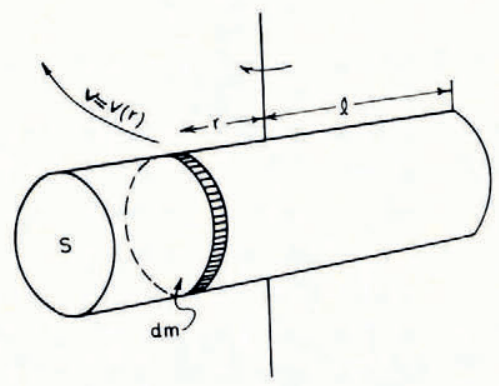

Fig. 6. Centrifugal test. 
The following in situ test has been developed: A snow pit is excavated, according to Fig. 7a. A flat aluminum plate, graduated in centimeters, is inserted into the pit wall (Fig. 7b), and then withdrawn quickly with a downward pressure. These two steps are repeated utilizing a deeper insertion of the plate each time until the cantilever beam fails (Fig. 7c). After removing the I or $2 \mathrm{~cm}$ of compressed snow which were destroyed by the downward pressure of the plate, the sequence can be repeated for the next $5 \mathrm{~cm}$ interval and so on down through the snow profile.
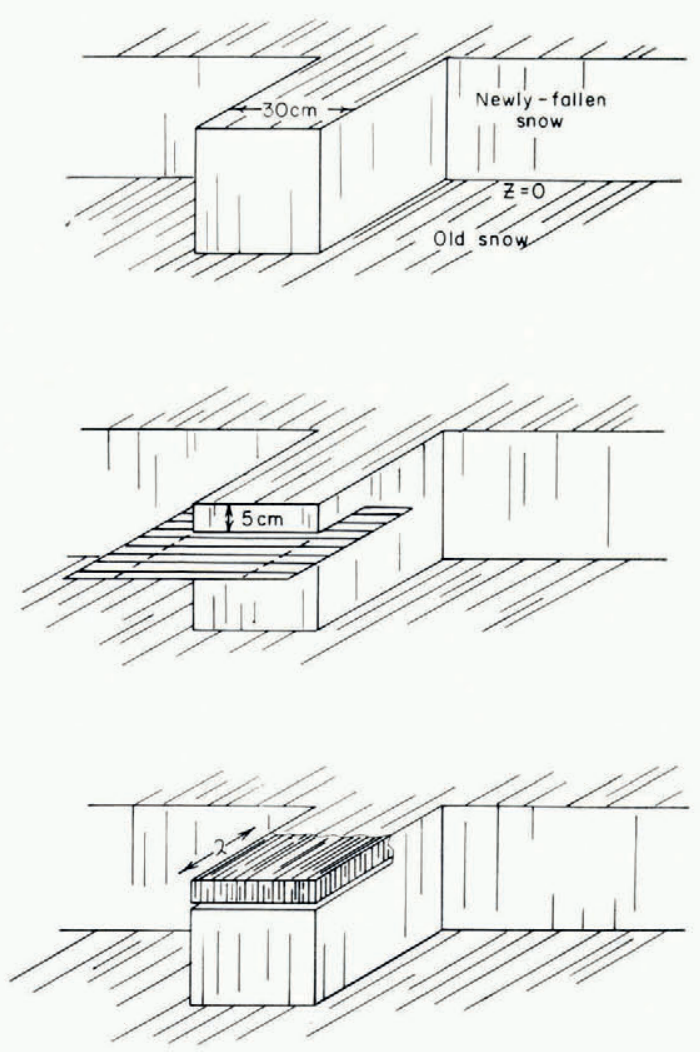

Fig. 7. a (top) Excavation of snow pit for cantilever beam test. $b$ (middle) Insertion of plate into pit wall.

$c$ (bottom) Failure of the cantilever beam at a length $\lambda$.

This test must be accompanied by a density profile taken at about $5 \mathrm{~cm}$ intervals. For newly fallen snow it is most convenient to collect density samples in cylindrical cans $\left(1000 \mathrm{~cm}^{3}\right.$ in volume or about $5 \mathrm{~cm}$ high and $8 \mathrm{~cm}$ in radius).

In situ beam tests have been applied to investigate the flexural properties of fresh ice and sea ice (Tabata and others, I967), but a search of the literature has not revealed any previous application of beam testing to low-density snow and the precise interpretation of snow beam data in terms of tensile strength is an open question.

Z. Yosida (personal communication) has suggested that a reasonable approximation to the tensile strength $\sigma$ sustained by the top fiber of the beam may be

$$
\sigma=\frac{M c}{I}
$$


where $M$ is the moment of the beam, $c$ the distance from the neutral axis to the top fiber and $I$ the second moment of area of the cross-section of the beam.

For a beam of length $\lambda$, thickness $L$, and density $\rho$, Equation (13) becomes

$$
\sigma=3 g \rho \lambda^{2} / L \text {. }
$$

Equation (14) is based on the symmetric stress distribution shown in Figure 8a. For other stress distributions, such as the unsymmetric case shown in Figure $8 \mathrm{~b}, \sigma$ is still of the order of $g \rho \lambda^{2} / L$. Following the analogy of the "ram number", a "beam number" $B$ can be defined as

$$
B=3 g \rho \lambda^{2} / L \text {. }
$$
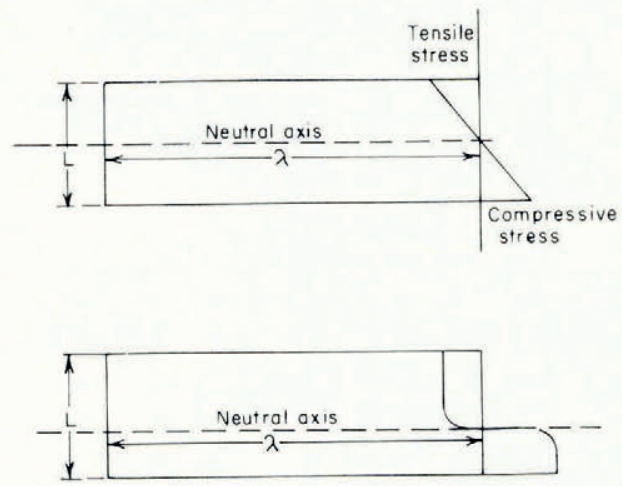

Fig. 8. a (top) Symmetric stress distribution of a cantilever beam.

$b$ (bottom) Unsymmetric case.

Values of $B$ are shown in Table II. It is expected that $B$ can be related to the tensile strength; perhaps as suggested by the above study, simply

$$
\sigma=k B
$$

where $k$ makes an adjustment appropriate to the stress distribution of the beam.

The foregoing analysis presupposes tensile failure. Observations of the beam fracture patterns (Fig. 9) do not verify that this is necessarily the case. In consideration of the possible role that shear failure plays, it is preferable to assert

$$
\sigma \geqslant k B \text {. }
$$
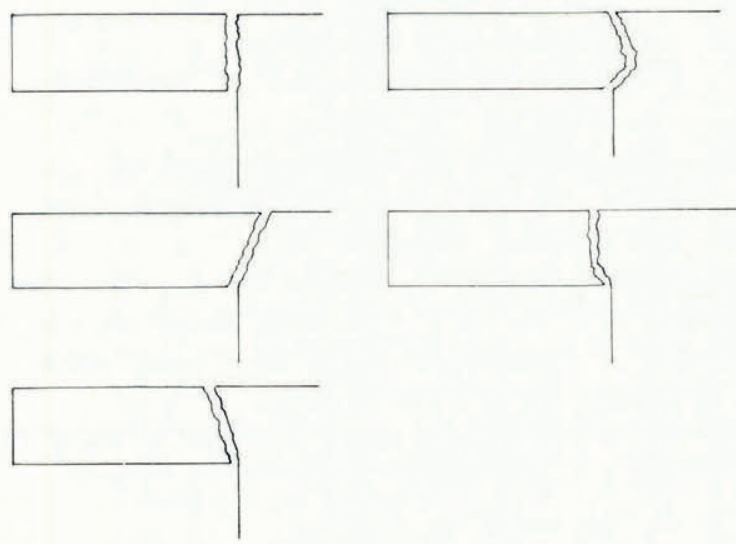

Fig. 9. Typical fracture patterns observed in the cantilever beam test. 
Three sequential profiles of newly fallen snow are shown in Figure io. For each layer, the "ram number" is plotted as a solid line and the "beam number" as a dashed line. The first profile, (a), was taken at the beginning of the storm, 17.00 h, 12 February I968; (b) was taken at og.oo h, I3 February I968; and (c) at i6.0o h, I3 February i 968.

In Table II, a comparison of $\tau$ and $B$, indicates that newly fallen snow is considerably stronger in tension than in shear. It is of interest that Keeler and Weeks (I968) shows Io : I for the ratio of tensile to shear strength while Roch (1965) shows up to $8: \mathrm{I}$. These high ratios are not easily reconciled with the standard theory of strength of materials which predicts

$$
\frac{\sigma}{\tau} \leqslant 2
$$
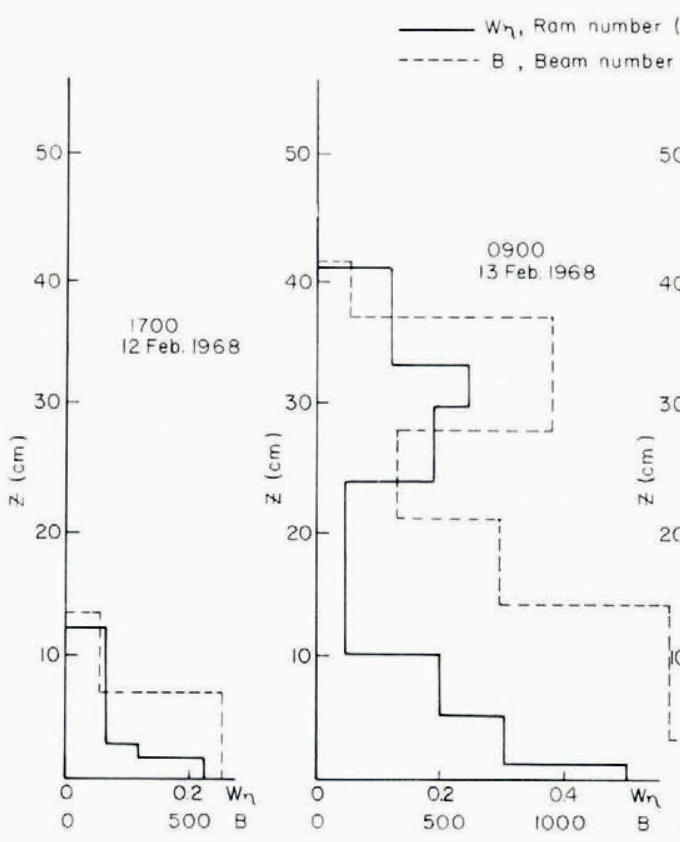

\section{$\mathrm{kg})$}

Fig. Io. Comparison of ram number (solid line) and beam number (dashed line). Newly fallen snow February 1968, Alta.

Since a simple tensile stress of $\sigma$ itself produces a shear stress of $\frac{1}{2} \sigma$ on planes at $45^{\circ}$ as can be seen from Mohr's circle construction.

Martinelli (in press) has also obtained relatively high ratios for tensile to shear strength but feels that these ratios reflect the peculiarities of the tests rather than the intrinsic strengths of the snow. In fact, R. Sommerfeld (personal communications) associates the reported high ratios with the stress concentrations that are introduced by vanes in the shear testing devices and the lack of the same in the tensile tests.

The distribution of $B$ with density is shown on a semi-logarithmic diagram (Fig. I I). Further investigations will be needed to determine if the order of magnitude variation in $B$ at all densities is a real variation in tensile strength as opposed to a peculiarity of the cantilever test. 


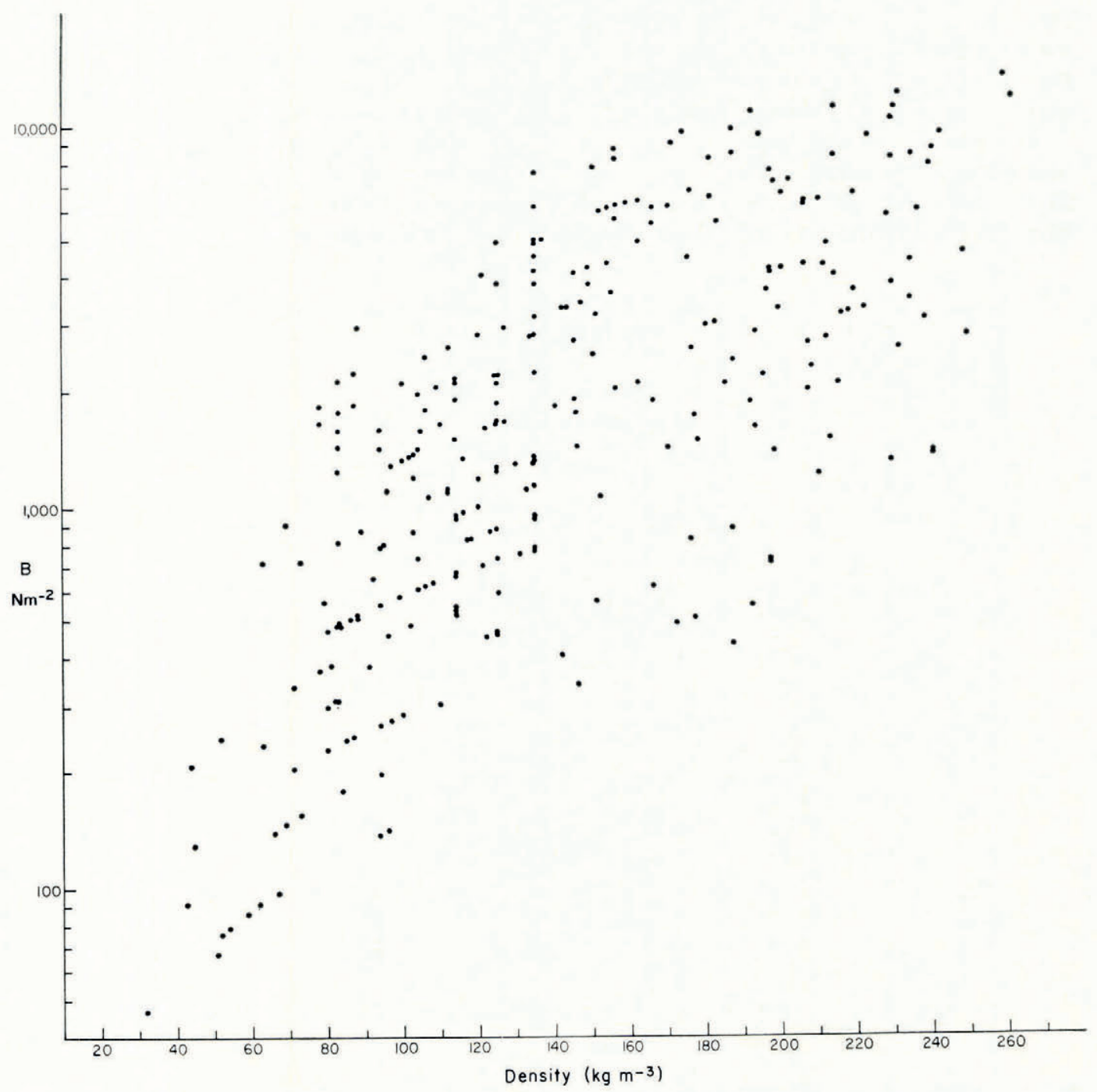

Fig. II. Beam number B plotted against density on a semi-logarithmic diagram, $1967-68$, Alta.

\section{Conclusions}

Preliminary studies at Alta have demonstrated that mechanical properties of newly fallen snow can be determined by a variety of simple in situ tests, most of which are well known and are at least self-consistent. These tests can all be performed during the most severe alpine weather. Future experiments are needed to establish the mutual consistency of these tests as well as their relationship to the intrinsic properties of the snow.

Generally speaking, penetration experiments are easy to perform but difficult to interpret. From drop-cone data, the "hardness number" can be calculated as

$$
\bar{P}=\frac{3 q p(p-1)}{4 \pi(p-2)} L^{p-3}
$$


and corrected "ram numbers" can be obtained from

$$
W_{\eta}=\frac{0.63 h / d+2}{h / d+2} W_{\mathrm{x}} .
$$

It may be possible to relate these numbers theoretically or experimentally to shear and tensile strengths.

Shear and tensile experiments, although more difficult to perform, are feasible if the apparatus is made light and large in comparison to the similar apparatus used on metamorphosed snow. Further development of the shear frame tests is needed to determine the Coulomb-Mohr behavior of newly fallen snow.

The cantilever test, despite problems of interpretation, gives an indication of the tensile strength in terms of a "beam number"

$$
B=3 g l \lambda^{2} / L
$$

The high ratio of tensile to shear strength reported here and in previous studies should receive more attention. It may be possible to either discover the mechanism in the crystal structure which permits this high ratio or alternatively show that peculiarities in the tests are responsible for this unexpected behavior.

When comparisons between these tests are established, the more expedient tests can be conducted at the fracture zone of avalanche paths.

\section{AcKnowledgements}

The drop-cone and lightweight penetrometer were designed by E. R. LaChapelle. The author gratefully acknowledges his guidance in this study. Many helpful suggestions were made by M. Martinelli, R. Sommerfeld, A. Judson and R. Schmidt of the Rocky Mountain Forest and Range Experiment Station. This study was financed by the Wasatch National Forest, Salt Lake City, Utah, and the Rocky Mountain Forest and Range Experiment Station, Fort Collins, Colorado.

MS. received 8 November 1968

\section{REFERENCES}

Anisimov, M. I. 1958. Sneg $i$ snezhnyye obvaly [Snow and snow avalanches]. Moscow, Izdatel'stvo Akademii Nauk SSSR. [English translation: U.S. Forest Service. Alta Avalanche Study Center. Translation I, 1963.]

Bader, H., and others. 1939. Der Schnee und seine Metamorphose, von H. Bader, R. Haefeli, E. Bucher, J. Neher, O. Eckel, C. Thams, P. Niggli. Beiträge zur Geologie der Schweiz. Geotechnische Serie. Hydrologie, Lief. 3. [English translation: U.S. Snow, Ice and Permafrost Research Establishment. Translation 14, 1954.]

Bader, H., and others. 1951. Preliminary investigations of some physical properties of snow, by H. Bader, B. L. Hansen, J. H. Joseph and M. A. Sandgren. U.S. Snow, Ice and Permafrost Research Establishment. Report 7.

Chellis, B. I96r. Pile foundations. New York, McGraw-Hill Book Co.

Hansbo, S. 1957. A new approach to the determination of the shear strength of clay by the fall-cone test. Proceedings. Royal Swedish Geotechnical Institute, No. 14.

Inaho, Y. I94I. Sekisetsu no kōdo ni tsuite [On the hardness of snow]. Seppyō, [Vol.] 3, [No.] 8, p. 343-49. [English translation: U.S. Snow, Ice and Permafrost Research Establishment. Translation 33, 1955.]

Keeler, C. M., and Weeks, W. F. 1968. Investigations into the mechanical properties of alpine snow-packs. Fournal of Glaciology, Vol. 7, No. 50, p. 253-71.

Kinosita, S. 1967. Compression of snow at constant speed. (In Ōura, H., ed. Physics of snow and ice: international conference on low temperature science. ... I966. . . . Proceedings, Vol. 1, Pt. 2. [Sapporo], Institute of Low Temperature Science, Hokkaido University, p. 911 -27.)

LaChapelle, E. R. 1967. The relation of crystal riming to avalanche formation in new snow. (In Oura, H., ed. Physics of snow and ice: international conference on low temperature science. . . I966. . . Proceedings, Vol. I, Pt. 2. [Sapporo], Institute of Low Temperature Science, Hokkaido University, p. i i69-75.)

Martinelli, M. In press. The physical and mechanical properties of freshly deposited snow in alpine areas. [To be issued by U.S. Forest Service. Rocky Mountain Forest and Range Experiment Station, Fort Collins, Colorado.] 
Mellor, M. 1964. Properties of snow. U.S. Cold Regions Research and Engineering Laboratory. Cold regions science and engineering. Hanover, N.H., Pt. III, Sect. AI.

Olson, R., and Flaate, K. I967. Pile driving formulas for friction piles in sand. Proceedings of the American Society of Civil Engineers, Vol. 93, No. SM6, p. 279-96.

Quervain, M. R. de. r950. Die Festigkeitseigenschaften der Schneedecke und ihre Messung. Geofisica Pura e Applicata, Vol. 18, p. r 79-91. [English translation: U.S. Snow, Ice and Permafrost Research Establishment. Translation 9, I95I.]

Roch, A. 1966. Les variations de la résistance de la neige. Union de Géodésie et Géophysique Internationale. Association Internationale d'Hydrologie Scientifique. Commission pour la Neige et la Glace. Division Neige Saisonnière et Avalanches. Symposium international sur les aspects scientifiques des avalanches de neige, 5-1o avril 1965, Davos, Suisse, p. 86-99.

Tabata, T., and others. 1967 . Studies of the mechanical properties of sea ice. XI. The flexural strength of sea ice in situ, by T. Tabata, K. Fujino and M. Aota. (In Oura, H., ed. Physics of snow and ice: international conference on low temperature science. ... 1966. ... Proceedings, Vol. I, Pt. I. [Sapporo], Institute of Low Temperature Science, Hokkaido University, p. 539-50.)

Takahashi, T., and Kudo, K. I941. Sekisetsu no kōdo shiken [Hardness test of snow]. Seppyō, [Vol.] 3, [No.l 6, p. 264-70. [English translation: U.S. Snow, Ice and Permafrost Research Establishment. Translation 40, 1955.]

Waterhouse, R. I966. Re-evaluation of the rammsonde hardness equation. U.S. Cold Regions Research and Engineering Laboratory. Special Report 100.

Yosida, Z., and others. 1957. Physical studies on deposited snow. III. Mechanical properties (2). Breakdown of snow by a falling body, by Z. Yosida, H. Oura, D. Kuroiwa, T. Huzioka, K. Kojima, S. Aoki and S. Kinosita. Contributions from the Institute of Low Temperature Science, No. I I, P. I-4I. 